\title{
REFLEKSI PENERAPAN \\ TEKNOLOGI INFORMASI DAN KOMUNIKASI DALAM \\ PENDIDIKAN DI INDONESIA \\ Sebuah Tinjauan Kritis
}

\section{Murti Kusuma Wirasti}

\begin{abstract}
As global social, economic and politic competition grows sharper, education becomes an important source of competitive advantage. Information and Communication Technology (ICT) is one of the main part for learning process improvement in Indonesia. Getting the best from ICT depends on several variables, including the appropriate design of hard technology, soft technology, and content; the training and attitude of instructors; and the realization that different students have different requirements. But we must respond critically and wisely. ICT is produced by some countries with several goals to get advantages from developing countries which have placed ICT as an important factor for human welfare improvement, closely linking with educational system. A decision made to use ICT in learning system must consider several factors consciously, such as socio-cultural and economic capabilities of our society. That is an approach to maintain our goals as free as developed countries in using ICT for education.
\end{abstract}

Key words: hard technology, soft technology, content.

PENDAHULUAN

Teknologi informasi dan komunikasi (TIK) adalah istilah yang seringkali diucapkan atau digunakan oleh berbagai pihak dalam beberapa tahun terakhir ini. Berbagai program dan kebijakan telah dibuat oleh berbagai pihak, baik perorangan maupun lembaga, atau baik oleh pemerintah maupun oleh swasta dan lembaga swadaya masyarakat. Pemerintah misalnya, telah mengeluarkan berbagai kebijakan yang berkenaan dengan penerapan teknologi informasi dan komunikasi, seperti: Nusantara 21, UU Nomor 36 Tahun 1999 Tentang Telekomunikasi, Keppres Nomor 50 Tahun 2000 tentang Tim Koordinasi Telematika Indonesia, Instruksi Presiden No. 6 Tahun 2001 tentang Pengembangan dan Pendayagunaan Telematika, atau Keppres No. 20 Tahun 2006 tentang Dewan Teknologi Informasi dan Komunikasi Nasional, dan kebijakan lainnya.

TIK telah menjadi sebuah orientasi yang dituju oleh semua pihak untuk menunjukkan ketercapaian kinerja suatu lembaga. Seperti pelaksanaan kepemerintahanan yang berbasis TIK, pendidikan berbasis TIK, ekonomi berbasis TIK, dan berbagai aspek yang mengarah pentingnya pengembangan dan pemanfaatan TIK di wilayah publik. Salah satu sektor yang menjadi wilayah pengembangan dan pemanfaatan TIK terbesar adalah sektor pendidikan. Berbagai program dan kebijakan dilakukan oleh berbagai pihak untuk mengembangkan TIK di berbagai lembaga pendidikan. Implikasi dari dilakukannya berbagai program dan kebijakan yang bertujuan untuk menunjang pendayagunaan pembelajaran berbasis TIK di lembaga pendidikan, adalah munculnya kebutuhan akan sumber daya manusia yang menguasai TIK, pengadaan dan pemeliharaan infrastruktur TIK, dan tentu saja implikasi finansial. Sementara implikasi yang spesifik, adalah implikasi pedagogis, kultural dan politis atas pengembangan TIK di lingkup pendidikan.

Sungguh, sebuah fenomena yang memberikan dampak luar biasa, hadirnya TIK di dalam kehidupan bangsa Indonesia dewasa ini. Akan tetapi, tinjauan yang bersifat kritis atas hadirnya TIK di dalam bidang pendidikan, bukanlah hal yang terlalu diperhatikan oleh banyak pihak. Kecenderungan untuk menerima TIK sebagai sebuah entitas eksternal yang telah memasuki wilayah publik dan pribadi jarang sekali dipahami secara komprehensif. TIK telah berusaha menjadi entitas internal yang hadir secara sadar di dalam kehidupan manusia. Kajian kritis dibutuhkan untuk menempatkan manusia sebagai penentu pemanfaatan TIK secara produktif untuk mendukung berbagai aspek kehidupan, termasuk bidang pendidikan. TIK perlu dipahami bukanlah sesuatu yang hadir secara netral, tanpa tekanan ideologis.

\section{PEMBAHASAN}

Tinjauan kritis: Tekanan Globalisasi dan Kapitalisme Internasional dalam Kehadiran TIK di Bidang Pendidikan di Indonesia

Tekanan internasional menyebabkan peningkatan kebutuhan akan teknologi pada masyarakat negara berkembang. Melalui berbagai 
forum internasional, misalnya di dalam Action Plan dalam World Summit Information Society (WSIS) di Geneva, Swiss (2003) dan Tunisia (2005), telah mentargetkan bahwa pada tahun 2015 terwujud jaringan komunikasi \& informasi dunia, dimana setengah penduduk dunia telah terhubung melalui jaringan internet dan intranet. Bahkan untuk lembaga pendidikan, diharapkan semua telah terhubung. Belum lagi judgement bahwa peningkatan penggunaan sarana telekomunikasi memberikan kontribusi di dalam produktivitas ekonomi sampai $30 \%$ yang disampaikan oleh International Telecommunication Union (ITU).

Dalam perspektif kritis, masyarakat kapitalistik yang menekankan pada basis material, bukan pada basis substantif dalam kehadiran teknologi, menganggap bahwa industrial kapitalistik adalah masyarakat yang disekat-sekat secara tidak adil menurut sekat-sekat tertentu, termasuk kelas sosial yang diciptakan dengan kehadiran teknologi. Negara berkembang dianggap berada pada kelas bawah dalam pergaulan internasional bahkan dianggap tidak ada, ketika tidak mampu memberikan penjelasan logis yang akuntabel pada aspek TIK di mata internasional. Padahal sesungguhnya jika melihat secara lebih kontekstual, maka pandangan-pandangan yang berbasis ideologis tersebut adalah hasil sebuah produksi realitas yang dikontruksikan oleh kelas atas internasional, dalam hal ini negara pemilik industri TIK, untuk kepentingan kentungan ekonomis semata (Storey, John, 2006:5).

Akan tetapi, realitas konstruktif ini telah dipandang sebagai sebuah realitas empiris yang membuat masyarakat, bahkan negara menganggap bahwa teknologi adalah sesuatu yang imperatif jika ingin menjadi bagian dari sebuah pergaulan internasional. Ketika sebuah masyarakat telah berada dalam jaringan internasional, maka mekanisme teknologis itu akan mendorong ke dalamnya. Sehingga teknologi bukanlah menjadi hanya sekedar kebutuhan, tetapi menjadi sebuah entitas eksternal tersendiri yang memaksa orang untuk menggunakannya. Kalau kebutuhan berasal dari dalam diri individu. Begitu kuatnya teknologi sebagai external entity, sebuah pluralitas eksternal yang menekan, memaksa masyarakat memiliki gaya hidup tersendiri, dan pada akhirnya bersifat sosial. Teknologi bukanlah sosial, tetapi karena sudah digunakan manusia dan semua orang beradaptasi dengan sebuah kultur baru, maka ia sudah menjadi entitas sosial yang memaksa.

Dunia tanpa batas (borderless world), tidaklah dipahami sebagai suatu paket yang utuh dalam usaha struktur internasional melakukan hegemoni menyeluruh di negara-negara berkembang, baik hegemoni politik, ekonomi, bahkan budaya. Marshal McLuhan menyebut sebagai global village atas tidak adanya batas antar negara yang diakibatkan oleh berbagai penetrasi internasional, atau kecenderungan yang diamati oleh Manuel Castells dengan masyarakat berjaringan dengan munculnya jaringan-jaringan di dalam masyarakat dunia, saat ini tengah terjadi di Indonesia. Tekanan dunia tanpa batas, memberikan kesempatan pada penguasa ekonomi dan teknologi untuk menjadikan negara-negara pengguna teknologi menjadi pasar ekonomi terbesar.

Bagaimana ketika untuk mencapai programprogram peningkatan kualitas sumber daya manusia melalui lembaga pendidikan, teknologi (dalam arti hardware dan software) menjadi kebutuhan utama. Pendidikan adalah pasar yang sangat besar bagi penguasa teknologi. Jumlah siswa di tingkat pendidikan dasar dan menengah di Indonesia adalah salah satu jumlah terbesar di dunia, sehingga Indonesia menjadi target pasar yang sangat menjanjikan bagi pemilik teknologi. Indonesia adalah konsumen yang sangat besar dalam hal hard technology, software technology, dan bahkan pada content technology.

Meskipun telah muncul alternatif-alternatif pilihan informasi yang dapat menjadi content technology pada pelaku pendidikan, akan tetapi sumber atau referensi masih mengacu pada apa yang disediakan oleh penguasa informasi dunia. Dapat terlihat jika kita membuka situs yang paling banyak diakses orang di dunia seperti google, maka kita dapat menghitung persentase yang sangat rendah yang diproduksi oleh penduduk negara berkembang. Hal inilah yang seharusnya disadari sepenuhnya oleh masyarakat negara berkembang, khususnya Indonesia.

\section{Pengaruh Kehadiran TIK di dalam Struktur Masyarakat Indonesia}

Teknologi informasi dan komunikasi merupakan produk teknologi tinggi dan modern yang dianggap berasal dari negara-negara maju. Bagi masyarakat Indonesia, teknologi informasi dan komunikasi merupakan inovasi yang diintrodusir secara meluas kepada masyarakat sejak pertengahan dekade 1990-an. Tawaran teknologi informasi dan komunikasi lebih masif lagi ketika masuk milenium ketiga, di mana pemerintah telah membangun jaringan infrastruktur teknologi informasi dan komunikasi hingga ke daerah perdesaan, terutama yang berkaitan dengan telekomunikasi.

Teknologi yang telah merasuk dalam kehidupan masyarakat, dan dengan terpaksa, suka atau tidak 
suka, orang harus beradaptasi dengan teknologi tersebut. Oleh karena itu, kita harus mengubah kultur masyarakat. Mempersiapkan masyarakat dalam menerima realitas tersebut sebagai bagian dalam kehidupannya menjadi hal yang penting. Misalnya, kultur interaksi secara face to face yang mengandalkan kultur lisan berubah ke dalam telephone interaction, atau kultur interaksi face to face yang mengandalkan kultur lisan menjadi electronic interaction melalui e-mail, sehingga menjadi kultur tersendiri, yaitu kultur menulis. Hal tersebut menjadi kendala bagaimana sebuah e-government yang dikembangkan oleh pemerintah dan swasta serta lembaga swadaya masyarakat tidak banyak digunakan oleh masyarakat daerah tersebut, karena kultur yang berbeda dengan layanan yang konvensional. ${ }^{1}$

Hadirnya teknologi komunikasi dan informasi, seperti ditunjukkan sebelumnya, telah mempunyai pengaruh yang luas dan kompleks terhadap masyarakat, baik secara struktural maupun kultural. Maka tidak mengherankan jikalau belajar dari hasil analisis Schiller (Webster, 1995) tentang pengalaman masyarakat negara-negara industri maju yang menunjukkan bahwa sebagai akibat ekspansi globalisasi informasi yang semakin jauh memasuki hampir setiap sektor kehidupan masyarakat, kini kita melihat kehadiran tiga ragam perubahan organisasi dan struktur masyarakat kita yang sangat problematis, yang di masa sebelum terjadinya krisis tahun 1997/ 1998 pun sebenarnya sudah hadir cukup nyata di hadapan mata publik. Pertama, di era globalisasi informasi, maka perkembangan informasi dan semua konsekuensi yang ditimbulkannya telah dan akan semakin bergeser dari perkembangan yang dikendalikan oleh kriteria-kriteria dan kekuatankekuatan politik menuju pada perkembangan yang dikendalikan oleh kriteria-kriteria dan kekuatankekuatan pasar. Dengan kata lain, inovasi-inovasi informasi dan komunikasi, yang akan menjadi kekuatan pendorong sangat penting bagi dinamika masyarakat kita di masa mendatang, akan berkembang semakin dikendalikan oleh kriteria-kriteria dan kekuatan-kekuatan pasar di dalam pembelian, penjualan, dan perdagangan untuk alasan keuntungan. Sentralitas prinsip-prinsip pasar di dalam ketiga kegiatan itu pada gilirannya akan menghasilkan terjadinya "komodifikasi" informasi, dan dengan demikian hanya akan menjamin ketersediaan informasi sejauh ia menghasilkan keuntungan; dan bagi para pengguna informasi, hanya akan dapat diperoleh sejauh mereka mampu membelinya. Kedua, globalisasi informasi telah dan akan mengakibatkan masyarakat dan ekonomi kita menjadi sebuah "corporate capitalism", suatu sistem kapitalisme yang semakin didominasi oleh institusiinstitusi korporatis di dalam bentuk organisasiorgansisasi bisnis oligopolitistis dan/atau monopolistis yang semakin jauh mengendalikan jangkauan nasional dan internasional mereka. Ketiga, dan yang tidak kalah pentingnya sebagai hasil dari keduanya, kesenjangan kelas (class inequality) juga telah dan akan semakin menguasai dinamika perkembangan masyarakat dan ekonomi kita di masa mendatang. Kelas, misalnya, telah dan akan semakin menentukan siapa yang akan memperoleh seberapa banyak dan jenis informasi macam apa beserta dengan semua konsekuensi yang ditimbulkannya. Di dalam situasi seperti itu, hanya mereka yang berada pada lapisan atas di dalam organisasi dan struktur sosial dan ekonomi kita, paling sedikit dalam jangka pendek, yang akan memperoleh keuntungan dari perkembangan masyarakat dan perkembangan teknologi informasi dan komunikasi.

Dengan kata lain, baik secara bersama-sama maupun sendiri-sendiri, ketiganya telah dan akan menghasilkan semakin menyempitnya ruang dan iklim publik, tempat masyarakat sipil dapat mengungkapkan aspirasi dan perspektif mereka. Sebagaimana sudah cukup jelas dapat kita pahami dari uraian di atas, di dalam iklim publik yang semakin lemah itu, ketiganya juga telah dan akan semakin membatasi akses mereka yang berada pada lapisan bawah struktur sosial masyarakat Indonesia untuk memanfaarkan setiap inovasi dan perkembangan teknologi informasi dan komunikasi sebagai salah satu pintu paling strategis untuk memasuki ruang kekuasaan ekonomi dan politik, bahkan kebudayaan tempat mereka melakukan kontemplasi, perenungan diri, pencerahan spiritual di hadapan misteri-misteri kehidupan yang dihadirkan Tuhan bagi umat manusia dalam kehidupan sehari-hari.

Semua itu menegaskan bahwa hubungan antara negara berkembang dan negara maju dalam jaringan komunikasi global menunjukkan perkembangan yang tidak seimbang. Setiap Negara di dunia memiliki koneksi sistem telepon internasional, penyiaran global dan jaringan data seperti internet. Di dalam semua Negara terdapat elit kecil yang memiliki akses dan pengalaman pada media baru. Istilah kecil sangat relatif, seperti kasus di India, dimana elit kecil ini menyangkut jutaan orang, karena jumlah populasi penduduknya yang tinggi. Elit tersebut bekerja di kota dan menjadi titik-titik yang terhubungan dengan jaringan global. 
Negara-negara seperti India dan Cina memiliki pengalaman dalam peningkatan penggunaan komputer yang terhubung internet. Dan pertumbuhan tercepat adalah pada kelas menengah di mana ratusan juta orang masuk dalam masyarakat jaringan. Kajian yang menempatkan aspek sosial ekonomi budaya sebagai faktor terpenting dalam penggunaan teknologi informasi dan komunikasi menuju peradaban baru membutuhkan kerangka konseptual yang komprehensif tentang arah peradaban yang dituju dan struktur sosial ekonomi budaya masyarakat itu sendiri.

Teknologi informasi dan komunikasi dianggap mendorong terjadinya globalisasi pada berbagai aktivitas seperti: politik, sosial dan ekonomi. Dengan peningkatan informasi global, dimana pengetahuan tentang bagaimana memperoleh keunggulan kompetitif dan informasi tentang siapa yang unggul lebih mudah tersedia, penggunaan dan diseminasi pengetahuan secara lebih efektif merupakan kunci untuk kesuksesan, sehingga pengembangan sosial dan ekonomi yang berkelanjutan merupakan keuntungan penggunaan teknologi informasi dan komunikasi. Inovasi, merupakan faktor penentu dalam kompetisi global. Inovasi berarti menggunakan ide-ide baru tentang bagaimana melakukan segala sesuatu secara lebih cepat dan lebih baik. Bagaimana membuat sebuah produk atau penawaran layanan, yang sebelumnya tidak pernah terpikirkan. Dan bagaimana mengambil ide-ide baru untuk bekerja dalam kemampuan kerja yang dapat menggunakan ide-ide baru. Dapat diasumsikan bahwa peningkatan teknologi informasi dan komunikasi memberikan implikasi pada sifat aktivitas politik, sosial dan ekonomi.

Pemanfaatan teknologi informasi dan komunikasi oleh masyarakat secara meluas dan optimal bagi kepentingan produktif bukanlah sematamata merupakan persoalan teknis seperti bagaimana orang harus dibekali kemampuan teknik-operasional, tetapi yang jauh lebih penting adalah bagaimana pemanfaatan teknologi informasi dan komunikasi itu merupakan perilaku budaya. Pemanfaatan teknologi informasi dan komunikasi berkaitan erat dengan aspek sosial dan budaya masyarakat, yakni bagaimana agar masyarakat secara mental dan kultural siap menerima hadirnya sistem atau teknologi baru, sehingga tidak memunculkan keterkejutan budaya (shock culture). Munculnya gejala gegar budaya sebagai implikasi hadirnya teknologi canggih, dapat menimbulkan kerugian besar, tidak saja secara ekonomi karena pengadaan perangkat kerasnya sangat mahal, tetapi juga secara kultural, dalam arti hilangnya kultur mandiri dan produktif yang berubah menjadi objek dari teknologi canggih. Karakter masyarakat yang sebelumnya mampu menjadi subyek dalam mengatasi persoalan hidup sehari-hari, bergeser menjadi masyarakat yang memiliki ketergantungan tinggi terhadap teknologi. Selain itu, kemampuan dalam membaca dan menulis (melek huruf) dan kemampuan menyusun kalimat menjadi hal yang penting. Belum lagi persoalan teknis tentang penggunaan perangkat kerasnya, bukan hanya persoalan pengadaan, tetapi bagaimana menyiapkan orang terbiasa menggunakan teknologi sebagai bagian kerja yang utama. Mengubah kultur tidak dapat dilakukan secara sekejap melalui workshop dengan jangka waktu pendek.

Hasil penelitian Litbang Depkominfo tahun 2006 menunjukkan bahwa semakin tinggi tingkat kemampuan ekonomi seseorang, maka semakin tinggi pula dalam mengakses informasi melalui internet. Fakta ini menguatkan tesis yang mengatakan bahwa kehadiran TIK hanya akan memapankan struktur sosial yang ada, jika tidak diikuti oleh perubahan struktur sosial itu sendiri. Artinya, TIK yang diharapkan mampu mengubah atau mempersempit kesenjangan sosial dengan menawarkan peluang mengakses informasi melalui teknologi murah, ternyata tidak terbukti. Justru kehadiran TIK mempertegas kesenjangan sosial, karena kepemilikan dan akses terhadap fasilitas informasi lebih banyak dilakukan oleh golongan masyarakat kuat secara ekonomi. Sedangkan masyarakat miskin tetap rendah dalam memanfaatkan fasilitas TIK (Depkominfo, 2006).

\section{Refleksi Empiris atas Hadirnya TIK di dalam Dunia Pendidikan di Indonesia}

Sebagai negara kepulauan dengan jumlah penduduk sangat besar yang tersebar di belasan ribu pulau, yang tersusun atas 33 propinsi, lebih dari 400 kabupaten/kota, lebih dari 5000 kecamatan, serta lebih dari 60.000 desa, menjadikan pencapaian berbagai kebijakan dan program yang berasal dari berbagai pihak tidak mudah mengingat kondisi geografis, sosiologis, dan budaya Indonesia yang sangat variatif tersebut. Realitas empirik sampai dengan tahun 2006, sekitar 50 \% (37.000 desa) daerah perdesaan belum terjangkau fasilitas telekomunikasi ${ }^{2}$, teledensitas kota $11-25 \%$, dan desa $0,2 \%$ atau teledensitas total adalah $4,49 \%$.

Realitas tersebut kemudian menjadi dasar di dalam perencanaan sejumlah kebijakan dan program untuk mengurangi kesenjangan digital (digital devide) di dalam struktur telekomunikasi dan informasi di Indonesia. Penetrasi teknologi telekomunikasi menjadi hal yang sangat penting di dalam peningkatan pemanfaatan TIK di Indonesia. Ketersediaan jaringan 
telekomunikasi akan mempermudah pemanfaatan TIK oleh masyarakat. Kesenjangan digital ini bukanlah kesenjangan infrastruktur antara desa dan kota saja, atau antara daerah maju dan kurang maju saja. Akan tetapi juga kesenjangan dalam bidang ekonomi, pendidikan, dan kesempatan yang justru mengakibatkan kesenjangan yang semakin tajam antara pihak yang memiliki akses informasi dan komunikasi dengan pihak yang kurang memiliki akses tersebut. Beberapa kajian yang telah dilakukan menunjukkan bahwa terdapat ketidaksiapan masyarakat Indonesia pada beberapa hal, terutama SDM, infrastruktur, ekonomi, sosial dan kultural. Di dalam bidang pendidikan misalnya, lemahnya kemauan untuk mengubah peran guru dari pemberi pengetahuan menjadi fasilitator belajar, kemampuan siswa yang bervariasi dalam penguasaan teknologi, ketersediaan fasilitas belajar dan lemahnya strategi dalam pemanfaatan TIK secara produktif menjadi beberapa bukti ketidaksiapan tersebut.

Di dunia pendidikan, refleksi empiris atas pelaksanaan sistem pendidikan berbasis TIK sesuai dengan program yang ditetapkan oleh berbagai satuan pendidikan dan lembaga terkait menunjukkan adanya variasi yang beragam baik dalam latar belakang pengambilan keputusan, dan operasionalisasi pelaksanaannya. Misalnya saja, ada beberapa sekolah yang telah membuka kelas ICT untuk beberapa kelas dengan standar tertentu, tetapi ada juga beberapa sekolah yang tidak dapat melaksanakan apapun karena adanya penolakan oleh orang tua siswa, atau bahkan ada sekolah yang tidak memiliki visi apapun atas penetrasi TIK di dalam program pendidikan nasional. Alangkah bervariasinya kondisi realistis yang terjadi di dalam masyarakat Indonesia.

Temuan sebuah kajian empirik atas pengembangan TIK di lingkup pendidikan pada tahun 2006 di sebuah desa yang dikategorikan terpencil di Pulau Sumatera, karena aksesibilitasnya sangat rendah, belum tersedia jaringan listrik dan belum memiliki infrastruktur TIK, terutama sarana telekomunikasi, menunjukkan bahwa masyarakat di wilayah ini telah memiliki orientasi yang sangat besar akan hadirnya TIK yang diharapkan akan mempermudah kehidupan mereka selanjutnya (Depkominfo, 2006).

"Selama ini saya belum pernah menyentuh komputer, bertahun-tahun di kantor ini saya hanya menggunakan mesin ketik. Saya bisa mengetik dengan sepuluh jari, dan meski saya guru tetapi saya juga mengurusi administrasi. Bapak Kepala Sekolah senantiasa menunjuk saya untuk mempersiapkan berbagai dokumen yang berkaitan dengan data kesiswaan maupun kepegawaian."
Sebuah pengakuan jujur itu diungkapkan oleh seorang guru di desa terpencil di desa tersebut yang begitu antusias ketika mendengar sekolahnya terpilih menjadi salah satu sekolah yang akan mendapat bantuan laboratorium komputer dari sebuah perusahaan besar melalui program pengembangan TIK bagi sekolah-sekolah di daerah terpencil. Dengan bersemangat ia bercerita, suatu saat nanti ia akan tinggalkan mesin ketik tua yang selama ini setia menemaninya. "Ya nanti jika komputernya sudah datang, ya pasti akan saya tinggalkan Pak mesin ketik itu. Gimana ya, kita ini kan harus maju, kalau pakai komputer itu kan namanya kemajuan Pak. Pokoknya saya akan berlatih agar bisa menggunakan komputer," ungkapnya dengan nada optimis. Meski belum pernah mencoba menggunakan komputer, bahkan untuk menyentuh pun belum, tetapi di benaknya sudah tertanam pandangan bahwa komputer itu sebuah simbol kemajuan dan modernitas. Sementara mesin ketik itu adalah simbol ketertinggalan. Ketika ia menyodorkan data-data kesiswaan dan guru, ia merasa perlu harus minta maaf dan malu-malu, karena masih ditulis dengan menggunakan mesin ketik. Namun ia tetap mengakui bahwa selama ini mesin ketik itu sangat berarti dalam menyelesaikan tugas-tugas administrasi. Ia menceritakan, bagaimana repotnya ketika mesin ketik itu rusak, padahal saatnya untuk menyerahkan laporan akhir semester. Terpaksa ia harus membuat laporan itu dengan tulisan tangan.

Temuan kajian tersebut hanyalah sepenggal kisah seorang guru di daerah terpencil, yang telah memiliki harapan yang sangat besar akan hadirnya TIK di lingkungannya. Pastilah situasinya jauh berbeda dengan sekolah-sekolah di daerah perkotaan yang sekarang kebanyakan sudah serba komputerisasi, dan bahkan sudah berjaringan. Administrasi persekolahan sudah terprogram dalam komputer, seperti untuk memasukkan dan menyimpan secara rapi dalam organisasi data yang terkomputerisasi. Termasuk jika ingin mengirimkan berkas dan informasi data laporan sekolah ke kantor dinas terkait, tinggal pencet tombol, dan dalam hitungan detik, data itu telah terkirim.

Di daerah terpencil, meski sudah berdiri bangunan gedung sekolah yang cukup bagus, tetapi sarana penunjang sangat tidak memadai. Laboratorium yang belum ada, perpustakaan sangat tidak memadai, dan bahkan ada yang belum punya, serta fasilitas media pembelajaran dan alat peraga yang praktis tidak ada. Akan tetapi, di daerah terpencil persoalan pendidikan tidak hanya berkisar pada bangunan fisik, tetapi justru pada permasalahan non- 
fisik seperti kurangnya SDM, input kemampuan siswa yang di bawah rata-rata, dan motivasi belajar yang masih rendah, serta distribusi buku paket yang tersendat. Sebagai penduduk di daerah terpencil, wawasan dan bagaimana memandang hidup sangatlah berbeda dengan masyarakat perkotaan. Jarang sekali warga desa yang memiliki cita-cita untuk meningkatkan taraf hidup melalui pendidikan. Kesadaran penduduk daerah terpencil terhadap arti penting pendidikan sangatlah rendah, karena itu bukan hal mudah untuk memotivasi warga agar tergerak menyekolahkan anaknya ke jenjang lebih tinggi. Banyak warga yang merasa tidak membutuhkan pendidikan sehingga malas pergi ke sekolah. Jika mereka lulus pendidikan dasar akan sangat sulit memotivasi mereka agar meneruskan ke sekolah menengah, atau apalagi ke jenjang perguruan tinggi.

Akan tetapi, kehadiran laboratorium komputer di sekolah di desa tersebut, ternyata berpengaruh pada cara pandang siswa dalam memandang arti penting pendidikan. Selama ini, siswa-siswi itu kebanyakan bercita-cita ingin jadi tentara, polisi, polisi wanita, dan guru. Tetapi setelah hadirnya laboratorium komputer, ada gejala mengubah cita-cita. Beberapa siswa mengaku timbul keinginan untuk meneruskan ke perguruan tinggi. Seorang siswa, Rohadi misalnya, dengan nada bersemangat menuturkan:

"Saya setelah mengenal dan sedikit dapat menggunakan komputer, saya ingin melanjutkan ke perguruan tinggi di kota. Kalau bisa saya akan masuk ke jurusan matematika. Tetapi kalau bisa ambil jurusan komputer sepertinya lebih bagus, dan nanti kalau lulus saya akan membuka usaha komputer di kampung saya sini. Kalau ada komputer error sekarang kami merasa susah karena tidak bisa memperbaiki, dan di sini belum ada yang bisa memperbaiki. Dan sekarang ini belum ada yang jualan disket di sini, kalau mau beli jauh sekali, harus ke kota kabupaten terlebih dahulu."

Sebuah gagasan yang cukup mengejut dan berpikiran ke depan itu keluar dari seorang siswa SMA di desa tersebut. Begitu tertariknya dia, hingga terobsesi untuk menjadi seorang ahli pemelihara komputer. Suatu perubahan yang luar biasa, jika mengingat di daerah ini dorongan untuk melanjutkan ke perguruan tinggi sangat kecil. Sebagai ilustrasi misalnya, lulusan angkatan terakhir (angkatan ke-7) dari 50 siswa yang lulus, hanya 5 orang yang melanjutkan studi ke perguruan tinggi.

Faktor keterbatasan ekonomi keluarga memang menjadi kendala utama rendahnya minat siswa melanjutkan studi ke perguruan tinggi. Akan tetapi, terbukanya pandangan siswa dan timbulnya motivasi siswa untuk berpikir ke depan setelah hadirnya komputer, tetap merupakan fenomena menarik. Kehadiran komputer ternyata mampu memompa semangat siswa untuk tahu lebih banyak, dan membuka cakrawala berpikir tentang bagaimana memaknai hidup. Kegelisahannya akan sulitnya mencari disket atau penyimpan data lainnya, memicu jalan pikirannya melompat ke depan. Ia sudah membayangkan bahwa daerahnya yang selama ini begitu sepi dan terpencil, nantinya akan menjadi berkembang berkat kehadiran perluasan jaringan teknologi informasi dan komunikasi.

Memang tidak semua siswa seperti Rohadi, tetapi setidaknya menjadi indikator nyata bahwa jalan pikiran orang, wawasan, dan pandangan dunianya dapat dipengaruhi oleh kehadiran sesuatu yang muncul dari luar dirinya. Pandangan kultural yang sebelumnya tertutup, menjadi terbuka dan seketika itu tumbuh kesadaran bahwa dirinya tertinggal dengan komunitas atau masyarakat di luar, maka hadirnya si pembuka wawasan yang terpaket dalam teknologi informasi dan komunikasi itu menjadi faktor yang menentukan. Perasaan tertinggal kemudian memicu motivasi untuk maju, untuk bisa lebih progresif seperti masyarakat luar sebagaimana yang dihadirkan oleh teknologi informasi dan komunikasi.

Keinginan untuk lebih maju, lebih meningkat kualitas hidupnya, tidak sekadar terjebak dalam kehidupan yang dibelenggu rutinitas, kemudian menyebabkan munculnya kegelisahan-kegelisan baru. Teknologi informasi dan komunikasi mempunyai kemampuan luar biasa dalam menciptakan kegelisahan pada masyarakat, karena di situlah yang menjadi dasar bagi teknologi informasi dan komunikasi telah tampil sebagai mesin penciptaan kebutuhan. Pada saat ini misalnya, ada sesuatu yang kurang dan bahkan terasa hilang, jika tidak membawa atau memiliki HP, membuka e-mail, atau sekadar main games di komputer. Padahal perasaan itu sama sekali tidak muncul, sebelum kehadiran TIK. Pada saat inilah proses kapitalisasi yang merasuk dalam struktur kesadaran masyarakat di berbagai wilayah Indonesia, termasuk di daerah terpencil mulai tertanam.

Mereka sebelumnya tidak begitu gelisah, kalau tidak berhubungan dengan sanak saudara yang jauh. Tetapi setelah hadirnya HP, keinginan berkomunikasi dengan sanak keluarga yang jauh, atau dengan teman, telah menjadi kebutuhan. Yang sebelumnya sebulan atau dua bulan tidak berkomunikasi, tidak menjadi permasalahan, sekarang menjadi terasa ada yang kurang jika dua atau tiga hari tidak melakukan komunikasi secara langsung. Intensitas berkomunikasi 
melalui sarana telekomunikasi menjadi semakin meningkat, dan keinginan berkomunikasi sudah menjadi kebutuhan, dan itu artinya meningkat pula anggaran biaya hidup. Belanja pulsa, penyimpan data, tinta printer, dan tentu saja energi listrik semakin menjadi kebutuhan sehari-hari.

Bagi siswa di daerah terpencil tersebut, kehadiran komputer menambah biaya pengeluaran sehari-hari, karena mereka harus membayar minyak solar untuk menghidupkan genset sebagai sumber energi listrik. Mereka mengeluarkan Rp 1000 rupiah untuk sekali masuk ke dalam laboratorium komputer, padahal uang saku mereka, biasanya hanya Rp 1000 setiap hari. Sekarang mereka harus menambah uang saku menjadi Rp 2000 jika di sekolah ingin menggunakan komputer. Bagi masyarakat di daerah perkotaan mungkin jumlah itu masih terasa sedikit, tetapi bagi masyarakat terpencil sudah cukup besar, karena itu mereka merasa cukup terbebani. Mereka sangat berharap agar ada bantuan untuk pengadaan energi listrik yang mengiringi hadirnya komputer, di samping harapan akan adanya instruktur yang benarbenar ahli di bidang komputer. "Uang saku saya setiap hari Rp 1000,-, tetapi kalau ada pelajaran komputer saya harus membawa uang saku menjadi Rp 2000 untuk biaya minyak solar. Terus terang saya agak keberatan dengan biaya itu, tapi ya bagaimana lagi, karena di sini memang belum ada listrik", ujar Taufik salah satu siswa.

Ke depan, sudah dapat diduga, bahwa jika siswa sudah mengenal lebih jauh tentang komputer dengan berbagai fasilitas baik untuk komunikasi dan yang bersifat rekreatif, maka hasrat untuk mengakses komputer akan semakin menjadi-jadi. Bisa dibayangkan jika mereka sudah mengenal chatting misalnya, tentu mereka akan lebih kecanduan lagi di hadapan komputer. Apalagi jika mereka sudah mengenal games dan berbagai menu yang menghibur lainnya, termasuk tampilan pornografi. Maka kebutuhan akan pemuasan hasrat semacam itu akan meningkat, dan tentu saja akan berimplikasi pada membengkaknya biaya hidup.

Hasil kajian empiris lainnya yang mendukung realitas tersebut menunjukkan bahwa masih dominannya kultur menonton di kalangan masyarakat merupakan kenyataan yang akan dihadapi dalam upaya membudayakan teknologi informasi dan komunikasi sebagai sarana pendidikan untuk mencerdaskan masyarakat. Pembangunan jaringan TIK ternyata kurang diikuti adanya transformasi kultural di kalangan warga, sehingga pemanfaatan teknologi informasi dan komunikasi hanya untuk keperluan rekreatif dan menghibur (Depkominfo, 2006).
Begitulah, serba-serbi sikap dan persepsi yang berkembang di kalangan siswa terhadap komputer, agaknya merupakan konsekuensi logis dari proses hadirnya teknologi baru dalam suatu masyarakat terpencil. Dari suatu masyarakat yang tadinya belum begitu kompleks kebutuhan hidupnya, menjadi semakin terdeferensiasi karena teknologi informasi dan komunikasi yang mampu menciptakan kebutuhankebutuhan baru.

Penciptaan kebutuhan yang disebabkan oleh tawaran berbagai fasilitas kemudahan yang akan diperoleh jika masyarakat menggunakan TIK, seperti kemudahan dalam menyelesaikan perhitungan matematis, pengolahan kata untuk bahasa, penyediaan fasilitas presentasi yang menarik, kemampuan dalam berhubungan secara langsung dengan berbagai pihak dari belahan dunia mana pun, atau kemampuan dalam menyimpan berbagai informasi dalam jumlah sangat besar dengan sistem yang mudah diakses, juga menjadikan TIK seolah menjadi imperatif bagi dunia pendidikan di Indonesia. Jika tidak menggunakan pendidikan berbasis TIK, maka ada kekhawatiran dianggap tidak maju, tidak modern, tidak sensitif terhadap perkembangan masyarakat, dan sejumlah tekanan lainnya. Kemasan inilah yang menjadi paket akan hadirnya TIK di dalam dunia pendidikan di Indonesia, dan juga sebagian besar negara berkembang lainnya.

\section{KESIMPULAN}

World view yang menentukan dan mekanis yang didominasi oleh pola pikir barat dalam pengembangan TIK di negara-negara berkembang membutuhkan proses adopsi yang berproses secara dinamik. Pemanfaatan harus mempertimbangkan dan merefleksikan kebutuhan dan kondisi sosial. Pengembangan ini berbasis pada realitas bukan berbasis pada model asing yang tidak sesuai dengan realitas aktual, yang terkadang tidak seuai dengan teori-teori formal yang diadopsi (Per Lind, 1991:157).

Indonesia sebagai negara yang telah masuk di dalam struktur hegemoni dunia internasional, seharusnya dapat lebih produktif dalam menghasilkan alternatif-alternatif pilihan melalui penciptaan hard technology, soft technology dan content technology yang sesuai dengan kondisi sosio kultural pendidikan di Indonesia. Jika pendidikan sebagai pasar terbesar bisnis TIK dunia, maka pelaku pendidikan harus berkelit dalam penentuan kebijakan dan program yang dilakukan secara sadar, bahwa teknologi adalah suatu entitas eksternal yang harus dikendalikan sesuai dengan kemampuan sosial dan kultural. 
Refleksi kritis secara terus menerus akan posisi tidak independen sangat dibutuhkan di dalam penentuan apa yang akan dipilih dan digunakan untuk menunjang peningkatan kualitas sumber daya manusia yang berbasis kultural, sehingga paling tidak kita sadar apa yang akan kita lakukan atas posisi kita sebagai konsumen dan pengguna TIK selama ini.

\section{DAFTAR PUSTAKA}

Departemen Komunikasi dan Informatika. (2006). “The sociocultural influences of computer laboratory appliance in partners in learning of microsoft Indonesia programme for 5 senior high schools in Kabupaten Waykanan, Lampung". Laporan Penelitian. Jakarta:Inpedham-Depkominfo.

Departemen Komunikasi dan Informatika. (2006). "Identifikasi kesiapan masyarakat secara sosio-kultural dalam menerima dan mengembangkan teknologi informasi di Indonesia". Laporan Penelitian. Jakarta: Litbang-Depkominfo.

David, T.H. \& Khrisna, S. (2005). The internet in Indonesia's new democracy. New York: Routledge

Per Lind. (1991). Computerization in developing countries: model \& reality. London: Routledge.
Roger, S. \& Eric, H. (1994). Consuming technologies: media and information in domestic spaces. London:Routledge

John, S. (2006). Pengantar komprehensif teori dan metode cultural studies dan kajian budaya pop.(Lailiy Rahmawati, penterjemah). Yogyakarta:Jalasutra

Adelin, T. (2005). Laba-laba media:Hidup dalam galaksi informasi, menurut pemikiran manuel castells. Jakarta:LSPP

Jan, V.D. (2006). The network dociety. Second Edition. London: Sage Publications Ltd.

Noel, W. \& Hartley. (ed). (1990). Technology in human communication. London: Pinter Publisher.

\section{KETERANGAN PENULIS}

R.A Murti Kusuma Wirasti, SIP.,M.Si., dilahirkan di Yogyakarta pada November 1974. Saat ini aktif sebagai dosen program studi Teknologi Pendidikan FIP UNJ. Telah menghasilkan banyak karya seperti penulisan diktat, penelitian, publikasi, dan makalah dalam pelatihan mulai dari tahun 1998 sampai dengan sekarang. 